\title{
Nasal Microbiology from Patients with Chronic Rhinosinusitis
}

\author{
MONICA GEORGESCU ${ }^{1}$, ALINA NICOLETA CAPITANESCU ${ }^{1}$, MIHAELA MITROI ${ }^{1}$, AURELIA ENESCU ${ }^{2}$, \\ G. MITROI ${ }^{3}$, MIHAELA JANA TUCULINA ${ }^{4}$, SMARANDA ADELINA PREDA ${ }^{5}$, \\ MARIA CRISTINA COMANESCU ${ }^{6}$, MĂDĂLINA OLTEANU ${ }^{4 *}$, CAMELIA MAGLAVICEANU-FIERA ${ }^{4}$, \\ FLOAREA MIMI NIȚU ${ }^{7}$, ROXANA MARIA NEMES ${ }^{8}$, SORIN IOAN TUDORACHE ${ }^{8}$, \\ ALEXANDRA FLORIANA NEMES ${ }^{9}$, FLORINA NECHITA ${ }^{10}$ \\ ${ }^{1}$ University of Medicine and Pharmacy, Department of Otorhinolaringology, 2 Petru Rares Str., 200349, Craiova, Romania \\ ${ }^{2}$ University of Medicine and Pharmacy of Craiova, Internal Medicine Department, 2 Petru Rares Str., 200349 Craiova, \\ Romania \\ ${ }^{3}$ University of Medicine and Pharmacy of Craiova, 2 Petru Rares Str., 200349 Craiova, Romania \\ ${ }^{4}$ Medicine and Pharmacy University of Craiova, Faculty of Dental Medicine, 2-4 Petru Rares Str., 200349, Craiova, Romania \\ ${ }^{5}$ University of Medicine and Pharmacy of Craiova, 2 Petru Rares Str., 200349 Craiova, Romania \\ ${ }^{6}$ University of Medicine and Pharmacy of Craiova, Department of Obstetrics and Ginecology, 2 Petru Rares Str., 200349 \\ Craiova, Romania \\ ${ }^{7}$ University of Medicine and Pharmacy of Craiova, Department of Pneumology, 2 Petru Rares Str, 200349, Craiova, Romania \\ ${ }^{8}$ Titu Maiorescu University, Faculty of Medicine, 22 Dambovnicului Str, 031593, Bucharest, Romania \\ ${ }^{9}$ Carol Davila University of Medicine and Pharmacy, 8 Eroii Sanitari Blvd, 020021, Bucharest, Romania \\ ${ }^{10}$ University of Medicine and Pharmacy of Craiova, Department of Medical Psychology, 2 Petru Rares Str., 200349, Craiova, \\ Romania
}

The purpose of this study is to establish if the germs that were identified in the bacteriological examination of nasal secretions of patients with CRS without nasal polyposis and patients with CRS with nasal polyposis are different.

Study design: cross-sectional

Keywords: microbiology, chronic rhinosinusitis

The European Position Paper on Rhinosinusitis and Nasal Polyps (EPOS, 2012), states that the prevalence of CRS is increasing annually. Epidemiological studies that explore the prevalence and incidence of CRS with or without nasal polyposis are deficient, especially in European countries - this was affirmed by the most important paper on the subject, EPOS [1].

Most recent data has demonstrated that CRS affects approximately $5-15 \%$ of the population in both Europe and the USA $[2,3]$.

Patients with CRS are now divided into those who have nasal polyps (CRSwNP) and those who do not (CRSsNP) [1].

The field has had many breakthroughs in the past few years, but the pathogenic mechanisms and triggering factors are not completely understood. Recently, the bacterial role of CRS pathogenesis has been the subject of intense debate, therefore the microbiology of CRS has been studied extensively [4,5].

Ethics statement. This study has been approved by the ethics committee of the University of Medicine and Pharmacy Craiova. All participants provided written informed consent prior to their participation in the project.

\section{Experimental part}

Materials and methods

We analyzed a number of 62 patients that have been diagnosed with CRS with/without nasal polyps that have been admitted in the ENT Clinic of County Emergency Hospital Craiova from January of 2016 to December of 2016.

The study included persons that were aged between 15 and 75, according to an EPOS suggestion [1].

EPOS states that the symptomatology of adults with CRS is [1]:

-The presence of two or more symptoms and at least one is nasal obstruction/congestion or rhinorrhea (anterior or posterior)

-With/without headache or facial pressure

-With/without hypo-/anosmia

-duration of symptoms should be at least 12 weeks, confirmed via telephone or face-to-face. 
At the recommendation of EPOS, we have excluded the next categories of patients that presented associated afflictions: cystic fibrosis diagnosed through the sweat test or DNA analysis, immunodeficiency syndrome (congenital or acquired), mucociliary congenital afflictions (e.g. primary ciliary dyskinesia), fungus-ball or invasive fungal sinusitis, systemic vasculitis, granulomatous diseases, cocaine abuse, cancer [6-14].

Furthermore, because our bacteriological study is based on tissue that comes from the meatus of patients with CRS, we also excluded patients that used systemic or local antibiotics the preceding month.

To appreciate how life-quality of patiens with CRS is affected, we used the SNOT-22 test, translated into Romanian [15]. This test scores between 0-110, depending on how much the symptoms of CRS affect the patient.

The clinical examination of the patients was done endoscopically and classically (anterior rhinoscopy) [16]. The endoscopic examination was done under local anesthesia-pulverizations with Lidocaine $10 \%$ and by using a $4 \mathrm{~mm}$ Storz telescope (KARL STORZ GmbH \& Co. KG, Tuttlingen, Germany).

\section{Sample Collection}

Samples for the microbiological examination were collected after using local anesthetics (Lidocaine 10\%) associated with xylometazoline ( 1 puff for each nasal fossa). Swabs were endoscopically guided (using a $0^{0}$ endoscope) to the middle meatus region and rotated at least 3 times. All samples were immediately transported to the laboratory.

The germs were isolated by inoculation of the tissue samples on proper culture medium - solid, semisolid, liquid, on plaques or tubes. The inoculated plaques and tubes were then incubated for $24-48 \mathrm{~h}$ at $37^{\circ} \mathrm{C}$ in a thermostat, in aerobiosis conditions for proper bacterial growth and multiplication.

The macroscopic aspect of the cultures (using the free-eye, simple lens or stereoscopic lens) guided our next steps. The cultures that were obtained on liquid or solid mediums were identified using morphological, biochemical antigenic and pathogenic criteria.

From an isolated colony, we inoculated a dispersion medium, until the manufacturers turbidity conditions were fulfilled and then verified with a MacFarland nonphelometric analyzer.

For the laboratory diagnostic of staphylococcal infections, smear tests were done on Methyl blue and Gram mediums from the pathological products and inoculations on simple liquid and solid culture mediums (simple gelosis) and complex mediums (blood-gelosis, Chapman). The incubation took place in aerobiosis at $37^{\circ} \mathrm{C}$.

The statistical analysis was done by using the Kruskal-Wallis and chi-square tests.

\section{Results and discussions}

Characteristic of the study-lot

The study included 62 patients that were diagnosed with CRS, with/without nasal polyposis, using the mentioned criteria. The age average of the entire lot was 48 , the age average of the women was 49 and of the men 46 . The conclusion is that the lot was age balanced (Table 1).

Table 1

THE DISTRIBUTION OF PATIENTS WITH CRS BY AGE AND GENDER

\begin{tabular}{|c|c|c|c|c|}
\hline & Average age & Standard deviation & Minimal age & Maximum age \\
\hline Total & 48 & 17.2 & 20 & 86 \\
\hline Women & 49 & 17.1 & 22 & 86 \\
\hline Men & 46 & 17.4 & 20 & 78 \\
\hline
\end{tabular}

We also noticed that the lot was gender balanced (Table 2) - $45 \%$ men(M) (28) and 55\% women(W) (34).

Table 2

DISTRIBUTION OF PATIENTS WITH CRS BY GENDER

\begin{tabular}{|l|l|l|}
\hline Women & 34 & $55 \%$ \\
\hline Men & 28 & $45 \%$ \\
\hline Total & $\mathbf{6 2}$ & $\mathbf{1 0 0 \%}$ \\
\hline
\end{tabular}

According to the medium of provenance, the patients were $29 \%$ from rural mediums (R) (18) and $71 \%$ from urban mediums (U) (44). We take note of the high percentage of patiens that are from urban mediums, approximately twice as many (Table 3). 
Table 3

DISTRIBUTION OF PATIENTS WITH CRS BY

THE MEDIUM OF PROVENANCE

\begin{tabular}{|c|c|c|}
\hline Rural & 18 & $29 \%$ \\
\hline Urban & 44 & $71 \%$ \\
\hline Total & $\mathbf{6 2}$ & $\mathbf{1 0 0 \%}$ \\
\hline
\end{tabular}

\begin{tabular}{|c|c|c|c|}
\hline & Rural & Urban & Total \\
\hline Women & 10 & 24 & $\mathbf{3 4}$ \\
\hline Men & 8 & 20 & $\mathbf{2 8}$ \\
\hline Total & $\mathbf{1 8}$ & $\mathbf{4 4}$ & $\mathbf{6 2}$ \\
\hline
\end{tabular}

By analyzing Table 3 we note that the patients with urban provenance are twice as many that those of rural provenance. The table also demonstrates that both men and women of urban provenance are twice as many than those of rural provenance, which was an expected situation, considering the fact that we established earlier the gender balance of the study lot.

From a clinical point of view, 45(72\%) patients have been diagnosed with CRSsNP and 17(28\%) with CRSwNP.

The age of the patients at the time of diagnosis will be the following: -Table 4

Table 4

DISTRIBUTION OF PATIENTS WITH CRSsNP AND CRSwNP BY AGE (KRUSKAL-WALLIS TEST, CHI-SQUARE TEST)

\begin{tabular}{|c|c|c|c|}
\hline & CRSsNP & CRSwNP & Statistical analysis* \\
\hline Number of patients & 45 & 17 & \\
\hline Age average (years) & 46 & 54 & $\mathrm{p}=0.0542$ \\
\hline Age average W (years) & 49 & 49 & $\mathrm{p}=0.8815$ \\
\hline Age average M (years) & 40 & 58 & $\mathrm{p}=0.0118$ \\
\hline Age average R (years) & 47 & 53 & $\mathrm{p}=0.6065$ \\
\hline Age average U (years) & 45 & 54 & $\mathrm{p}=0.0929$ \\
\hline M/W Raport & $18 / 27$ & $10 / 7$ & $\mathrm{p}=0.1840$ \\
\hline
\end{tabular}

Considering this table, we note the following:

-the age of patients with CRSsNP is not significantly different than that of patients with CRSwPP ( $p>0.05)$

-the age of female patients with CRSsNP is not significantly different than that of female patients with CRSwNP (p $>0.05)$

-the age of male patients with CRSsPP is significantly different than that of male patients with CRSwNP $(\mathrm{p}<0.05)$

-the age of $\mathrm{R}$ patients with CRSsNP is not significantly different than that of R patients with CRSwNP $(\mathrm{p}>0.05)$

-the age of U patients with CRSsNP is not significantly different than that of U patients with CRSwNP $(p>0.05)$

-The patient lots that have been diagnose with CRPsNP and CRSwNP are omogenous. There are no significant differences. There is no statistical evidence that can indicate that women are more likely to have CRSsNP or CRSwNP, rather than men $(\mathrm{p}>0.05)$

Also:

-there are 4 times as many women with CRSsNP (27) than women with CRSwNP (7)

-there are 2 times more men with CRSsNP (18) than with CRSwNP (10)

-the patients of rural provenance have twice as many CRSsNP (12) than those with CRSwNP (6)

-the patients with urban provenance have 3 times as many CRSsNP (33) than CRSwNP (11)

-altogether, from the 62 patients lot, approximately a quarter have CRSwNP and 3/4 have CRSsNP

We have calculated the differences between the age average of patients with CRSsNP vs. CRSwNP

-of the entire lot, the age average of patients with CRSsNP is 46 years old, and for those with CRSwNP is 54

-for women, the age average of those with CRSsNP is approximately equal with those with CRSwNP (49)

-for men, the age average of those with CRSsNP (40) is a lot smaller than those with CRSwNP (58)

All patients have completed the SNOT-22 test that analyses the life-quality of patients with CRS. The average SNOT22 score is analyzed in Table 5. 
Table 5

CRSsNP AND CRSwNP ANALYSES AND AVERAGE SNOT-22 SCORE

\begin{tabular}{|c|c|c|c|}
\hline & CRS & CRS+NP & $\begin{array}{c}\text { Statistical } \\
\text { analyses* }\end{array}$ \\
\hline $\begin{array}{c}\text { Number of } \\
\text { patients }\end{array}$ & 45 & 17 & \\
\hline SNOT-22 average & 58.8 & 69.8 & $\mathrm{p}=0.1339$ \\
\hline
\end{tabular}

For the statistical analyses we used the Kruskal-Wallis test. The conclusion of Table 5 is that the SNOT-22 average score of patients with CRSsNP is not significantly different than that of patients with CRSwNP ( $p>0.05)$.

SNOT-22 average for the entire lot is 61.8; for women the average score is 66.9 and for men 55.7. This shows a significant difference between SNOT-22 average scores of women vs. men - $p=0.0639$ ( $p>0.05)$ according to the KruskalWallis test (Table 6)

Table 6

SNOT-22 AVERAGE SCORE BY GENDER

\begin{tabular}{|c|c|c|c|c|}
\hline & $\begin{array}{c}\text { SNOT-22 } \\
\text { average }\end{array}$ & Standard deviation & $\begin{array}{c}\text { SNOT-22 } \\
\text { minimum }\end{array}$ & $\begin{array}{c}\text { SNOT-22 } \\
\text { maximum }\end{array}$ \\
\hline Entire lot & 61.8 & 22.3 & 21 & 106 \\
\hline Women & 66.9 & 21.3 & 31 & 106 \\
\hline Men & 55.7 & 22.2 & 21 & 95 \\
\hline
\end{tabular}

\section{Bacteriological analyses of nasal secretions of patients with CRS}

Of the 62 samples we have studied, 32 (52\%) showed no microorganisms growth; in 30 samples (48\%) we have found aerobic bacteria. We did not find anaerobic microorganisms (Table 7).

\begin{tabular}{|l|c|c|c|}
\hline Type of bacteria & $\begin{array}{c}\text { Number of } \\
\text { patients }\end{array}$ & CRSsNP & CRSwNP \\
\hline Citrobacter & 2 & 1 & 1 \\
\hline E Coli & 1 & 1 & 0 \\
\hline Klebsiella & 3 & 2 & 1 \\
\hline Proteus & 3 & 2 & 1 \\
\hline Staphylococcus haemolyticus & 1 & 1 & 0 \\
\hline Staphylococcus aureus & 19 & 16 & 3 \\
\hline Streptococcus alfa & 1 & 1 & 0 \\
\hline No development & 32 & 21 & 11 \\
\hline Total & $\mathbf{6 2}$ & $\mathbf{4 5}$ & $\mathbf{1 7}$ \\
\hline
\end{tabular}

Of the 62 patients, $32(52 \%)$ did not develop any germs and 30 patients (48\%) developed one of the seven: White Staphylococcus haemolyticus (1 patients), Alpha Streptococcus (1 patient), E. Coli (1 patient), Citrobacter (2 patients), Proteus (3 patients), Klebsiella (3 patients), Staphylococcus aureus (19 patients). Therefore, out of all the patients that developed one of the seven types of germs (30), those that developed Staphylococcus aureus (19) represent 63\%. This means $2 / 3$ out of all the patients that developed a germ (19 out of 30$)$.

Of the patients that have been diagnosed with CRSsNP (45), 21 (47\%) have not developed any type of germ; of the 24 patients with CRS that developed a germ, most of them developed Staphylococcus aureus $(16$ patients $=67 \%)$.

Out of the patients diagnosed with CRSwNP (17), 11 patients (65\%) did not develop any germs; of the 6 patients with CRSwNP that developed a germ,most of them were Staphylococcus aureus ( 3 patients $=50 \%$ ).

Out of the 32 patients that have not developed any type of germ, $21(66 \%)$ have been diagnosed with CRSsNP and 11 (34\%) with CRSwNP.

Out of the 19 patients that developed Staphylococcus aureus, 16 (84\%) have been diagnosed with CRSsNP and $3(16 \%)$ with CRSwNP.

We did not notice differences between the germ that developed in women vs.men and this contradicts data from specialty literature. In a study that was published in 2017 Golan notes that Staphylococcus aureus is most likely present in men [17]. Females are more susceptible to allergic rhinitis during menstruation and pregnancy $[18,19]$ 
Chronic rhinitis has a high prevalence in smoking patients [20,21, 22, 23]. The sleep-apnea syndrome can be associated with allergic rhinitis, but it doesn't determine the severity of the disease [24, 25]. Another risk factor for rhinitis can be low serum levels of hemoglobin [26, 27].

The role of microorganisms in the pathogenesis of CRS, undisputed for decades, has been vigorously debated in recent years. There is not enough evidence to support the classic bacterial theory, and CRS is no longer considered to be a consequence and result of recurrent acute inflammation episodes. Because of the germ diversity that we have found in the nasal mucosa, there are authors that consider [28] the presence of germs found in the nasal mucosa irrelevant in the physiopathology of CRS.

Many previous investigations addressed CRS microbiology using conventional culture-dependent techniques. Under these conditions, the most common pathogens identified were aerobic bacteria - S. aureus and coagulase-negative Staphylococci $[3,29,30]$, negative -Gram bacilli [31].

Our study analyses the differences of the bacteriological examination of patients with CRSsNP and CRSwNP. The study protocol allwed us to take samples only from the middle nasal meatus. Our study included CRS patients free of acute exacerbation.

Some authors explain the existence of CRS forms that are resistant to medical therapy caused by intracellular persistence of $S$. aureus in the mucosa of the nasal cavity and paranasal sinuses [32]. However, data on the presence of S. aureus in the nasal cavity and paranasal sinuses are quite diverse and largely depend on the sampling method and culturing technique. For example, one study examined the middle nasal meatus microbiology and recovered S. aureus in 36\% of the cases of CRS patients, and in 39\% of those from healthy subjects [33], and 40\% developed Staphylococcus [34]. Another study identified S. aureus in swabs from the inferior turbinate of CRS patients (50\%) and of healthy individuals (33\%) [35].

In our study we take notice of the frequency of the germs isolated from the middle meatus of CRS patients: Staphylococcus aureus is most commonly found, followed by the Gram-negative bacilli (Klebsiella and Proteus). Mantovani [36] also identifies Gram-negative in CRS patients, especially Pseudomonas aeruginosa. We only isolated Citrobacter in 1 patient,and this contradictes the speciality literature. because Stern [37] states that Citrobacter is the most commonly found Gram-negative germ isolated from the nasal secretions of CRS patients.

\section{Conclusions}

In our study, $63 \%$ of the probes were positive for Staphylococcus aureus. This meant it has the highest frequency in both CRSsNP (67\% of the positive probes) and CRSwNP (50\% of the positive probes). Gram-negative bacteria have also been isolated, placing them as second in frequency: $8 \%$ out of the positive probes in patients with CRSsNP and $32 \%$ in patients with CRSwNP.

There were no significant differences in the microbiological features of the middle meatus samples from CRSsNP patients and CRSwNP patients.

More studies are needed to completely elucidate the role of bacteria in the pathogenesis of CRS, in particular by comparing the density and composition of the microbiological community that resides in the nasal cavity and paranasal sinuses under acute exacerbation conditions and remission periods.

\section{References}

1.WYTSKE J. FOKKENS, VALERIE J. LUND, MULLOL, J., CLAUS BACHERT, C., et al, Rhinology supplement 23 : 1-298, 2012 2.HASTAN D, FOKKENS WJ, BACHERT C, et al, Allergy 2011; 66(9): 1216-1223.

3.MIHAELA MITROI, ALINA CAPITANESCU, CLAUDIA VALENTINA GEORGESCU et al, Romanian Journal of Morphology and Embryology 2011, 52(3 Suppl):1051-1057

4.MITROI, MR; GEORGESCU, M; CAPITANESCU, AN, AMARASCU, M, Romanian Journal of Rhinology, 2014

5.MARINA AMARĂSCU, ELENA IONIŢĂ, MIHAELA MITROI, Current Health Sciences Journal Vol. 38, No. 4, 2012 October December 6. ALBULESCU D. M., PREDA A. S., CAMEN A., IONOVICI N., Rev.Chim. (Bucharest) 69, no. 7, 2018, p. 1692-1694

7.ALBULESCU D.M., IONOVICI N., MOLDOVAN H., DEMETRIAN A., BALA S., CONSTANTIN C., PANUS C., ALBU V. C., Rom J Morphol Embryol 2017, 58(2):545-551

8.ALBU C.V., PĂDUREANU V., BOLDEAN M.V., BUMBEA A. M., ENESCU A. Ş., ALBULESCU D. M., SILOȘI C. A., ENESCU A. J Mind Med Sci. 2018; 5(1): 7-15

9.PREDA S. A., NECHITA F., COMANESCU M. C., ALBUlESCU D. M., TUCULINA M. J., DOCEA A. D., BURADA E., VASILE R. C., MITROI M., Rev. Chim. (Bucharest), 70, no.6, 2019, p. 2054-2057

10. POPESCU M., CARSOTE M., GHEMIGIAN A., IONOVICI N., CALBOREAN V., DINESCU V. C., ALBULESCU D. M., Rev.Chim.

(Bucharest), 69, no. 8, 2018, p. 2089-2091

11.NECHITA, D., NECHITA F., MOTORGA R., Rom J Morphol Embryol 2018, 59(4):1045-1051

12.NITU, FM., OLTEANU, M., STREBA CT. et al., Rom J Morphol Embryol., 58, no. 2, 2017, p:385-392.

13.MAN MA, NITU MF, STRAMBU L et al. RJME, 57, no 1, 2016, p:237-242

14.NEMES RM, IANOSI ES, POP CS et al. RJME, 56, no 2, p:521-525

15.CĂPITĂNESCU, A.N., MITROI, M.R., MITROI, I.B. - ORL. ro, 2018 
16.S. OBREJA, ELENA IONIŢĂ, MIHAELA MITROI, I. IONIŢĂ - Îndreptar terapeutic ORL, Editura Sitech Craiova 2010

17.GOLAN Y, GAVRIEL H, LAZAROVICH T, EVIATAR E, Eur Arch Otorhinolaryngol. 2017 Jul;274(7):2803-2807. doi: 10.1007/s00405-0174560-5. Epub 2017 Apr 13.

18.ELLEGARD EK. Am J Respir Med, 2 no 6, 2003, p:469-475

19.TUDORACHE IS, TOADER OD, PETRESCU E, RUSU E et al. Rev. Chim. (Bucharest), 70, no 5, 2019, p.1703-1706

20.CHIARELLA SE, GRAMMER L. Expert Rev Clin Immunol, 13, no 2, 2017, p:117-123

21.IANOSI ES., DANTES E., CSIPOR A., SZATHMARY M., SOCACI A., RUSU E., NEMES RM. Rev Chim (Bucharest), 69, no 10, 2018, p.2725-2727

22.IANOSI ES, POSTOLACHE P, MACOVEI LA et al. Rev. Chim. (Bucharest), 69, no 7, 2018, p:1766-1769

23.LESAN A, MAN MA, NEMES RM, HARSOVESCU T, TUDORACHE IS, MAHLER-BOCA B, POP CM. Rev Chim (Bucharest),70, no 7, 2019, p:2410-2414

24.ZHENG M, WANG X, GE S et al J Clin Sleep Med, 13, no 8, 2017, p:959-966

25.MOTOC NS, MAN MA, TUDORACHE IS, RUSU E, BRAILESCU CM, MAHLER-BOCA B et al. Rev Chim. (Bucharest), 70, no 9, 2019, $\mathrm{p}: 3273-3276$

26.BENER A, EHLAYEL M, HAMID Q. Indian Journal of Allergy, Asthma and Immunology 29, no 2, 2015, p:72-78

27.NEMES RM, POP CS, CALAGIU D, DOBRIN D, CHETROIU D, JANTEA P, et al. Revista medico-chirurgicala a Societatii de Medici si Naturalisti din Iasi. 120, no 1, 2016, p:34-9.

28.CLELAND EJ, BASSIOUNI A, WORMALD PJ., Int Forum Allergy Rhinol. 2013 Aug;3(8):642-6. doi: 10.1002/alr.21159. Epub 2013 Mar 6. 29.COFFEY CS, SONNENBURG RE, MELROY CT, DUBIN MG, SENIOR BA., Am J Rhinol. 2006 Jan-Feb;20(1):72-6.

30.IVANCHENKO O.A, KARPISHCHENKO S.A, KOZLOV R.S., KRECHIKOVA O.I., OTVAGIN I.V., SOPKO O.N., PISKUNOV G.Z., LOPATIN A.S., Rhinology 2016; 54: 68-74.

31.OLADEJI SM, NWAWOLO CC, FASUNLA AJ, ELIKWU CJ, EZEAMAGU CO, Afr J Med Med Sci. 2016 Jun;45(2):135-141.

32.PLOUIN-GAUDON I, CLEMENT S, HUGGLER E, CHAPONNIER C, FRANCOIS P, LEW D, et al, Rhinology 2006; 44(4): $249-254$.

33.ARAUJO E, DALL C, CANTARELLI V, PEREIRA A, MARIANTE AR, Am J Rhinol 2003; 17(1): 9-15.

34.NIGRO JF, NIGRO CEN, MARONE SAM, VOEGELS RL, Braz J Otorhinolaryngol 2006; 72(2): 217-222.

35.KREMER B, JACOBS JA, SOUDIJN ER, VAN DER VEN AJ, Eur Arch Otorhinolaryngol 2001; 258 (5): $220-25$.

36.KARINA MANTOVANI, ANDRÉIA ALESSANDRA BISANHA, RICARDO CASSIANO DEMARCO, EDWIN TAMASHIRO, ROBERTO MARTINEZ, WILMA TEREZINHA ANSELMO-LIMA, Braz J Otorhinolaryngol 2010; 76 (5): 548-51.

37.STERN S, HADAR T, NACHALON Y, BEN-ZVI H, SOUDRY E, YANIV E., 2016;78(4):223-31. doi: 10.1159/000446188. Epub 2016 Jul 19.

Manuscript received: 18.11 .2019 